\title{
Eu(III) doped LDH intercalated with cinnamate anion as multifunctional sunscreens
}

\author{
Gustavo Pereira Saito ${ }^{a}$, João Henrique Saska Romero ${ }^{a, b}$, Marco Aurélio Cebim ${ }^{\text {a }}$, \\ Marian Rosaly Davolos ${ }^{\mathrm{a}, *}$

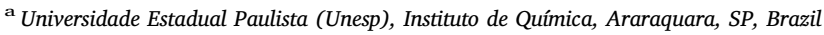 \\ ${ }^{\mathrm{b}}$ Instituto Federal de Educação, Ciência e Tecnologia do Estado de São Paulo, Catanduva, SP, Brazil
}

\section{A R T I C L E I N F O}

\section{Keywords:}

$\mathrm{Zn}_{2} \mathrm{Al}-\mathrm{LDH}$

Europium(III)

Intercalation

UV protection

Red light

Sunscreens

\begin{abstract}
A B S T R A C T
Eu(III) doped $\mathrm{Zn}_{2} \mathrm{Al}-\mathrm{LDH}$ intercalated with cinnamate anions with different $\mathrm{C}_{9} \mathrm{H}_{7} \mathrm{O}_{2}{ }^{-} / \mathrm{M}^{3+}$ molar ratios were synthesized by different anion-exchange methods. The XRD patterns indicate the formation of hydrotalcite-like compounds. UV-VIS absorption spectra show that the hybrid materials obtained have UV shielding capacity. PLS measurements show low-intensity red light emission of the characteristic europium and cinnamate ions that is recommended to induce collagen production.
\end{abstract}

\section{Introduction}

The excessive exposure to solar radiation causes sunburns, irregular skin pigmentation, premature aging, immune system function modifications and skin cancer [1]. Therefore, sun protection is essential to our physical and mental well-being. The necessity to protect people's skins from the harms caused by sun radiation has significantly promoted the development of materials with great UV radiation protection, high photochemical stability and low toxicity, i.e., new sunscreens $[2,3]$. Depending on the sunscreen composition, besides UV protection, this type of material may achieve other beneficial functions to the organism such inducing collagen production. Collagen is the main fibrillar protein responsible for the skin's viscoelastic properties and its biosynthesis by fibroblasts is induced by the incidence of low-intensity radiation in the spectral region of $580-700 \mathrm{~nm}[4,5]$, which also includes the red-light.

Multifunctional sunscreens may be obtained by doping inorganic host matrices with metal ions and/or by intercalating ionic species into them, such as layered double hydroxides (LDH). The LDH, also known as hydrotalcite-like compounds or anionic clays, have two-dimensional structures organized with flexible pores. These materials are capable of having negative species intercalated in the interlayer region in order to neutralize the positive charges of the layers. Thus, the species inserted in the interlayer spacing acquire extra stability through electrostatic interactions [6]. In general, $\mathrm{LDH}$ present themselves as having the following formula $\left[\mathrm{M}_{(1-\mathrm{x})}^{2+} \mathrm{M}_{\mathrm{x}}^{3+}(\mathrm{OH})_{2}\right]\left(\mathrm{A}^{\mathrm{n}-}\right)_{\mathrm{x} / \mathrm{n}} \cdot \mathrm{zH}_{2} \mathrm{O}(\mathrm{M}=$ metal ions and
$\mathrm{A}^{\mathrm{n}-\mathrm{-}}=$ interlayer anion) and a structure derived from brucite mineral [7]. The intercalation of chromophore species in LDH has been widely reported in the literature [8-10] due to the broad-spectrum sunscreens that were obtained having low toxicity and high chemical, thermal and/or photochemical stability. Besides, LDH doped with metal ions, especially lanthanide ions presenting luminescent properties, have been the subject of studies in recent scientific publications [11-13]. The growing interest in LDH doping is related to future 2D applications of these materials in several areas [7].

In this perspective, the $\mathrm{Eu}^{3+}$ ion, which has an intense red-light emission and is used as a spectroscopic probe for the determination of local structures [14] due its intraconfigurational 4-4 $\mathrm{f}$ transitions, can be highlighted. Moreover, the red-light emission of the $\mathrm{Eu}^{3+}$ ion can be improved by inserting a sensitizer into the compound of interest, which then performs the energy transfer process. The energy transfer is suitable if there is an interaction between both chemical entities [15]. Therefore, the study of intercalating chromophore species in the LDH doped with $\mathrm{Eu}^{3+}$ ions is of great significance for the development of new multifunctional sunscreens. Thus, this work aims to investigate potential multifunctional sunscreens obtained by the interaction of 3phenyl-2-propenoic acid (cinnamic acid) sunscreen, in its anionic form, in the $\mathrm{Zn}_{2} \mathrm{Al}$-LDH matrix doped with $\mathrm{Eu}^{3+}$ ions to emphasize the materials spectroscopic characterization.

\footnotetext{
* Corresponding author.

E-mail address: davolos@iq.unesp.br (M.R. Davolos).
} 


\section{Experimental}

\subsection{Sample preparation}

Zinc chloride $\left(\mathrm{ZnCl}_{2}-99.98 \%\right.$, Vetec), aluminum chloride hexahydrate $\left(\mathrm{AlCl}_{3} \cdot 6 \mathrm{H}_{2} \mathrm{O}-99.98 \%\right.$, Synth), Europium oxide $\left(\mathrm{Eu}_{2} \mathrm{O}_{3}-\right.$ 99.99\%, CSTARM), cinnamic acid $\left(\mathrm{C}_{9} \mathrm{H}_{8} \mathrm{O}_{2}-99.99 \%\right.$, Sigma-Aldrich), hydrochloric acid ( $\mathrm{HCl}-99.98 \%$, Qhemis) and sodium hydroxide (NaOH $-98.67 \%$, Synth) were used without further purification. The europium chloride $\left(\mathrm{EuCl}_{3}\right)$ solution was prepared by dissolving the solid $\mathrm{Eu}_{2} \mathrm{O}_{3}$ in a hydrochloric acid solution; the sodium cinnamate salt $\left(\mathrm{NaC}_{9} \mathrm{H}_{7} \mathrm{O}_{2}\right)$ was obtained by mixing $\mathrm{C}_{9} \mathrm{H}_{8} \mathrm{O}_{2}$ and $\mathrm{NaOH}$, at a 1:1 molar ratio, in a mixed solution of ethanol and water. $\mathrm{LDH}$ were synthesized by the coprecipitation method at constant $\mathrm{pH}$ [16]. A mixed solution of zinc, aluminum $\left(\mathrm{Zn}^{2+} / \mathrm{Al}^{3+}\right.$ molar ratio equal to 2) and europium chloride $\left(1.0 \mathrm{~mol} \%\right.$ of $\left.\mathrm{Eu}^{3+}\right)$, in the case where $\mathrm{Eu}^{3+}$ substitutes for $\mathrm{Al}^{3+}$, was added slowly and under stirring to $150 \mathrm{~mL}$ of deionized water at room temperature and nitrogen atmosphere. The solution $\mathrm{pH}$ was adjusted to 6.5 by the addition of a $0.2 \mathrm{~mol} \mathrm{~L}^{-1}$ solution of $\mathrm{NaOH}$. The suspension was kept under stirring for $3 \mathrm{~h}$ in nitrogen atmosphere. The solid obtained was filtered, washed with deionized water and dried at room temperature for $24 \mathrm{~h}$. For the preparation of hybrid materials, the doped LDH was added in a solution of sodium cinnamate salt $\left(\mathrm{C}_{9} \mathrm{H}_{7} \mathrm{O}_{2}{ }^{-}\right.$) $\mathrm{M}^{3+}$ molar ratio equal to 5 or 7) and the suspension obtained was subjected to hydrothermal treatment for $24 \mathrm{~h}$ at $100{ }^{\circ} \mathrm{C}$ or to stirring for 14 days at room temperature. The solids were filtered, washed with deionized water and ethanol and dried at room temperature for $24 \mathrm{~h}$. The hybrid material obtained by stirring with $\mathrm{C}_{9} \mathrm{H}_{7} \mathrm{O}_{2}{ }^{-} / \mathrm{M}^{3+}=7$ molar ratio was designated $\mathrm{Zn}_{2} \mathrm{Al}_{1-\mathrm{x}} \mathrm{Eu}_{\mathrm{x}}-\mathrm{Cnm}_{7}-\mathrm{LDH} / \mathrm{S}$ and hybrids obtained by hydrothermal treatment with $\mathrm{C}_{9} \mathrm{H}_{7} \mathrm{O}_{2}{ }^{-} / \mathrm{M}^{3+}=5$ or 7 molar ratios were designated as $\mathrm{Zn}_{2} \mathrm{Al}_{1-\mathrm{x}} \mathrm{Eu}_{\mathrm{x}}-\mathrm{Cnm}_{5}-\mathrm{LDH} / \mathrm{HT}$ and $\mathrm{Zn}_{2} \mathrm{Al}_{1-\mathrm{x}} \mathrm{Eu}_{\mathrm{x}}-\mathrm{Cnm}_{7}-\mathrm{LDH} /$ HT, respectively.

\subsection{Characterization techniques}

X-ray diffraction (XRD) patterns of powdered samples were recorded on a Rigaku diffractometer, model RINT 2000, using $\mathrm{CuK} \alpha$ radiation $\left(1.5418 \AA, 40 \mathrm{kV}, 70 \mathrm{~mA}\right.$, scan $2 \theta$ range $3-70^{\circ}$ and scan speed $0.02^{\circ} / 10 \mathrm{~s}$ ) and $\mathrm{Ni}$ filter. FTIR spectra were collected in the $4000-368 \mathrm{~cm}^{-1}$ region in a Bruker spectrophotometer, model FTIRVertex70, using the ATR method. Diffuse reflectance spectra of powdered samples were recorded on a Perkin Elmer spectrophotometer, model LAMBDA 1050 UV-VIS-NIR, equipped with Spectralon $150 \mathrm{~nm}$ integrating sphere. Color index was obtained in a Konica Minolta spectrophotometer, model CM-2500d, equipped with $\mathrm{d} / 8^{\circ}$ integrating sphere (CIELab color space). The emission and excitation spectra were recorded in a Fluorolog Horiba Jobin Yvon spectrophotometer, model FL3-222, using a continuous xenon lamp irradiation source ( $450 \mathrm{~W}$ ) and a Hamamatsu R928 photomultiplier. Molecular modeling of the cinnamate anion was performed by semi-empirical calculations in the MOPAC2016 software, using the Sparkle/RM1 model with the keywords: BFGS, XYZ, SPARKLE, RM1, GNORM $=0.25$, PRECISE and CHARGE $=-1$ (see Table S1 and Fig. S1 in the Supplementary Material).

\section{Results and discussion}

\subsection{Structural analysis}

Comparing the XRD patterns of samples (Fig. 1) with the JCPDSPDF-89-460 card corresponding to hydrotalcite-like compound (rhombohedral unit cell and space group $R 3 \mathrm{~m}$ ) and also comparing them to a series of layered double hydroxides described in the literature [17], it is observed the LDH formation have good structural organization and phase purity. In the XRD patterns of the LDH, the diffraction peaks situated above $30^{\circ} / 2 \theta$ are assigned to brucite-like layer

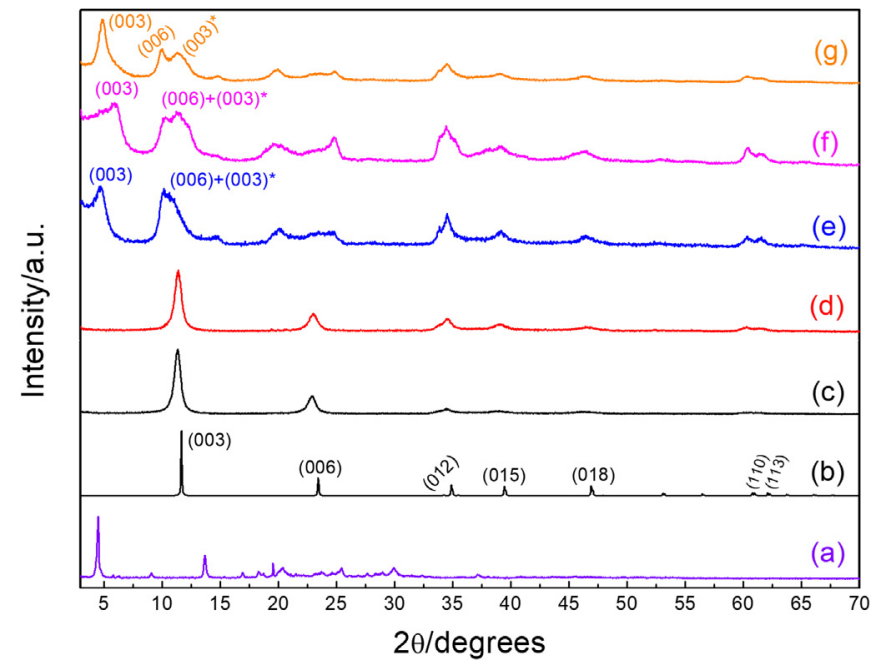

Fig. 1. XRD patterns of (a) sodium cinnamate salt, (b) JCPDS-PDF-89-460 card, (c) $\mathrm{Zn}_{2} \mathrm{Al}-\mathrm{Cl}-\mathrm{LDH}$, (d) $\mathrm{Zn}_{2} \mathrm{Al}_{1-\mathrm{x}} \mathrm{Eu}_{\mathrm{x}}-\mathrm{Cl}-\mathrm{LDH}$, (e) $\mathrm{Zn}_{2} \mathrm{Al}_{1-\mathrm{x}} \mathrm{Eu}_{\mathrm{x}}-\mathrm{Cnm}_{5}-\mathrm{LDH} / \mathrm{HT}$, (f) $\mathrm{Zn}_{2} \mathrm{Al}_{1-\mathrm{x}} \mathrm{Eu}_{\mathrm{x}}-\mathrm{Cnm}_{7}-\mathrm{LDH} / \mathrm{HT}$ and (g) $\mathrm{Zn}_{2} \mathrm{Al}_{1-\mathrm{x}} \mathrm{Eu}_{\mathrm{x}}-\mathrm{Cnm}_{7}-\mathrm{LDH} / \mathrm{S}$.

structures, while the harmonic reflections (001) located in low-angle $2 \theta$ region are attributed to layer stacking, which is directly associated to intercalated anions [18]. Thus, basal spacing is calculated from the interplanar distances $\left(\mathrm{d}_{h k l}\right)$ of the respective basal reflections. So, $a$ parameter is equal to interplanar distance $\mathrm{d}_{110}$ multiplied by 2 and $c$ parameter is defined as interplanar distance $\mathrm{d}_{003}$ multiplied by 3 for the LDH compounds with rhombohedral symmetry $R 3 m$ such as the layered materials obtained above [17].

Analyzing the $\mathrm{d}_{003}$ values of $\mathrm{Zn}_{2} \mathrm{Al}-\mathrm{Cl}-\mathrm{LDH}$ and $\mathrm{Zn}_{2} \mathrm{Al}_{1-\mathrm{x}} \mathrm{Eu}_{\mathrm{x}}-\mathrm{Cl}-\mathrm{LDH}$ (Table 1) against the values reported in literature [19], it is observed that the anion in greater quantity in the interlayer region is the chloride ion, which has $\mathrm{d}_{003}$ close to $7.8 \AA$. The presence of chloride ions inside the interlayer space facilitates the intercalation the anion of interest, especially by using the method of synthesis described above to obtain the hybrid materials, because chloride anions have a low capacity of stack assembly when compared to other anions, mainly the carbonate ion [19].

For the $\mathrm{Zn}_{2} \mathrm{Al}_{1-\mathrm{x}} \mathrm{Eu}_{\mathrm{x}}-\mathrm{Cl}$-LDH sample, detailed modifications in the $a$ and $c$ parameters are observed (Table 1 ). Those parameters refer to the distances between cations of the LDH layers and the distances between three consecutive layers, respectively. Modifications among them are associated with point distortions of the LDH crystalline lattice caused by the insertion of small quantities of the $\mathrm{Eu}^{3+}$ ion [11]. The XRD

Table 1

Interplanar distances $\mathrm{d}_{003}$ and $\mathrm{d}_{110}$, lattice parameters ( $a$ and $c$ ), basal and interlayer spacing of samples.

\begin{tabular}{|c|c|c|c|c|c|c|}
\hline Sample & $d_{003}$ & $d_{110}$ & $a / \AA ̊$ & $c / \AA ̊$ & $\begin{array}{l}\text { Basal } \\
\text { spacing /Å }\end{array}$ & $\begin{array}{l}\text { Interlayer } \\
\text { spacing }^{\mathrm{b}} / \AA\end{array}$ \\
\hline $\mathrm{Zn}_{2} \mathrm{Al}-\mathrm{Cl}-\mathrm{LDH}$ & 7.80 & 1.54 & 3.08 & 23.40 & 7.77 & 2.97 \\
\hline $\begin{array}{l}\mathrm{Zn}_{2} \mathrm{Al}_{1-\mathrm{x}} \mathrm{Eu}_{\mathrm{x}}-\mathrm{Cl}- \\
\mathrm{LDH}\end{array}$ & 7.76 & 1.53 & 3.06 & 23.28 & 7.75 & 2.95 \\
\hline $\mathrm{Zn}_{2} \mathrm{Al}_{1-\mathrm{x}} \mathrm{Eu}_{\mathrm{x}^{-}}$ & 18.56 & 1.54 & 3.08 & 55.68 & 17.92 & 13.12 \\
\hline $\begin{array}{l}\mathrm{Cnm}_{5^{-}} \\
\mathrm{LDH} / \mathrm{HT}\end{array}$ & $8.72^{\mathrm{a}}$ & & & $26.16^{\mathrm{a}}$ & $8.18^{\mathrm{a}}$ & $3.38^{\mathrm{a}}$ \\
\hline $\mathrm{Zn}_{2} \mathrm{Al}_{1-\mathrm{x}} \mathrm{Eu}_{\mathrm{x}^{-}}$ & 15.24 & 1.53 & 3.06 & 45.72 & 15.33 & 10.53 \\
\hline $\begin{array}{l}\mathrm{Cnm}_{7^{-}} \\
\mathrm{LDH} / \mathrm{HT}\end{array}$ & $7.71^{\mathrm{a}}$ & & & $23.13^{\mathrm{a}}$ & $7.73^{\mathrm{a}}$ & $2.93^{\mathrm{a}}$ \\
\hline $\mathrm{Zn}_{2} \mathrm{Al}_{1-\mathrm{x}} \mathrm{Eu}_{\mathrm{x}^{-}}$ & 18.26 & 1.54 & 3.08 & 54.78 & 17.95 & 13.15 \\
\hline $\begin{array}{l}\mathrm{Cnm}_{7^{-}} \\
\mathrm{LDH} / \mathrm{S}\end{array}$ & $7.76^{\mathrm{a}}$ & & & $23.28^{\mathrm{a}}$ & $7.68^{\mathrm{a}}$ & $2.88^{\mathrm{a}}$ \\
\hline
\end{tabular}

${ }^{\text {a }}$ LDH intercalated with chloride ions.

$\mathrm{b}$ Interlayer spacing corresponds to the difference between basal spacing and brucite-like sheet thickness (4.8 $)$. 

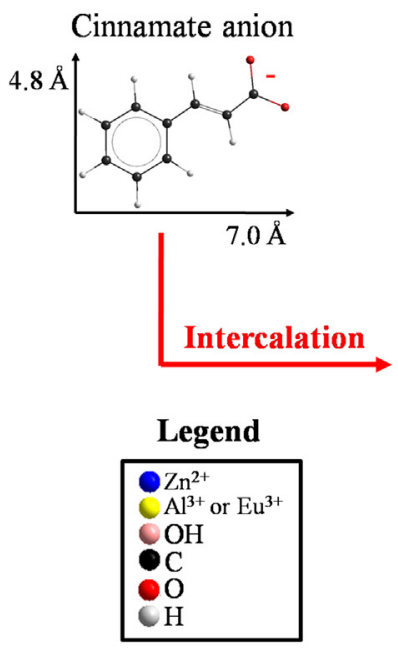

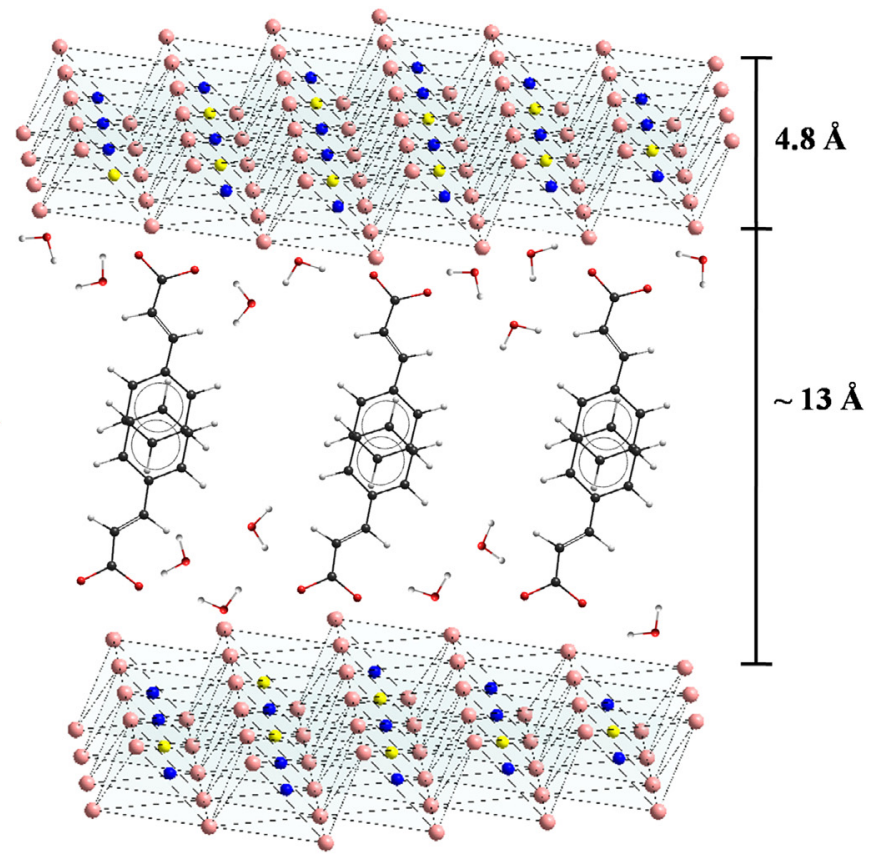

Fig. 2. Probable schematic representation of the interlayer arrangement for the cinnamate anion in hybrid materials.

patterns of the hybrid materials show the displacement of basal reflections to smaller angles when compared with those of $\mathrm{Zn}_{2} \mathrm{Al}_{1-\mathrm{x}} \mathrm{Eu}_{\mathrm{x}}-\mathrm{Cl}-$ $\mathrm{LDH}$ and $\mathrm{Zn}_{2} \mathrm{Al}-\mathrm{Cl}-\mathrm{LDH}$ (reference samples). This displacement indicates the increase of basal distance (Table 1) caused by the intercalation of the cinammate anion. However, it is observed that hybrid materials are composed of both LDH intercalated with cinammate anions and LDH intercalated with chloride anions. Considering the cinnamate anion dimensions achieved by semi-empirical calculations $(4.8 \times 7.0 \AA)$ and the interlayer distance of the hybrids, a bilayer arrangement of the organic anion in the interlayer region is proposed, where the carboxyl groups of the cinnamate anion are close to the positive LDH layers and the aromatic rings are stacked one with other (Fig. 2).

The FTIR spectra (Fig. 3) of the hybrid materials show characteristic bands of the cinnamate anion, such as the $\mathrm{C}^{=} \mathrm{C}_{\text {alkene }}$ stretching $\left(1639 \mathrm{~cm}^{-1}\right)$ and the $C^{=} C_{\text {ring }}$ stretching $\left(1450 \mathrm{~cm}^{-1}\right)$, and typical bands of the LDH host assigned to hydroxyl stretching vibrations $\left(3346 \mathrm{~cm}^{-1}\right)$

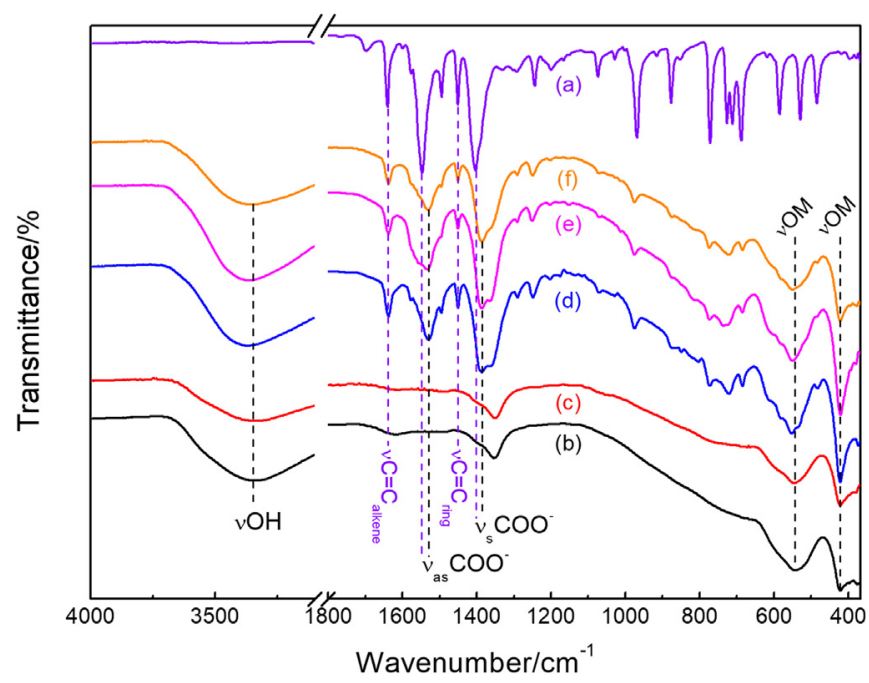

Fig. 3. FTIR spectra of (a) sodium cinnamate salt, (b) $\mathrm{Zn}_{2} \mathrm{Al}-\mathrm{Cl}-\mathrm{LDH}$, (c) $\mathrm{Zn}_{2} \mathrm{Al}_{1}$ ${ }_{x} \mathrm{Eu}_{\mathrm{x}}-\mathrm{Cl}-\mathrm{LDH}$, (d) $\mathrm{Zn}_{2} \mathrm{Al}_{1-\mathrm{x}} \mathrm{Eu}_{\mathrm{x}}-\mathrm{Cnm}_{5}-\mathrm{LDH} / \mathrm{HT}$, (e) $\mathrm{Zn}_{2} \mathrm{Al}_{1-\mathrm{x}} \mathrm{Eu}_{\mathrm{x}}-\mathrm{Cnm}_{7}-\mathrm{LDH} / \mathrm{HT}$ and (f) $\mathrm{Zn}_{2} \mathrm{Al}_{1-\mathrm{x}} \mathrm{Eu}_{\mathrm{x}}-\mathrm{Cnm}_{7}-\mathrm{LDH} / \mathrm{S}$. and also the metal-oxygen vibrational modes (544 and $422 \mathrm{~cm}^{-1}$ ) [20]. Moreover, the carboxylate bands $\left(\nu_{\mathrm{as}} \mathrm{COO}^{-}=1529 \mathrm{~cm}^{-1}\right.$ and $\nu_{\mathrm{s}} \mathrm{COO}^{-}=$ $1385 \mathrm{~cm}^{-1}$ ) are shifted to a lower wavenumber when compared to those of the cinammate anion $\left(\nu_{\mathrm{as}} \mathrm{COO}^{-}=1547 \mathrm{~cm}^{-1}\right.$ and $\nu_{\mathrm{s}} \mathrm{COO}^{-}=$ $1402 \mathrm{~cm}^{-1}$ ). This vibrational shift indicates that interactions between host layers and cinnamate anions occur through the carboxylate group as proposed in Fig. 2. The carboxylate groups of cinnamate anions can be coordinated to metal ions in different ways; therefore, the frequency difference between $\mathrm{COO}^{-}$asymmetric and symmetric stretching modes $\left(\Delta \nu=\nu_{\text {as }} \nu_{\mathrm{s}}\right.$ ) gives information about the coordination mode [21]. According to the $\Delta \nu$ values obtained, the carboxylate groups are bound to the metal ions from the layers via a bridging bidentate mode.

\subsection{Optical properties}

According to structural analysis, hybrid materials have similar structural organization, thus the $\mathrm{Zn}_{2} \mathrm{Al}_{1-\mathrm{x}} \mathrm{Eu}_{\mathrm{x}}-\mathrm{Cnm}_{7}-\mathrm{LDH} / \mathrm{S}$ sample was chosen as reference to investigate the optical properties of the hybrid materials as multifunctional sunscreens.

The UV-VIS reflectance diffuse spectra (Fig. 4a) show that each material has a specific visible-light scattering $(400-800 \mathrm{~nm})$, which is correlated with particle size and/or aggregate formation. The UV-VIS absorption spectra of the samples obtained by the Kubelka-Munk equation [22] are shown in Fig. 4b. The absorption spectrum of $\mathrm{Zn}_{2} \mathrm{Al}$ Cl-LDH exhibits bands in the $200-280 \mathrm{~nm}$ region, which are attributed to $\mathrm{VB} \rightarrow \mathrm{CB}$ transitions of the $\mathrm{LDH}$. The $\mathrm{Zn}_{2} \mathrm{Al}_{1-\mathrm{x}} \mathrm{Eu}_{\mathrm{x}}-\mathrm{Cl}-\mathrm{LDH}$ spectrum has both typical $\mathrm{LDH}$ bands and low intensity absorption bands of $\mathrm{Eu}^{3+}$ ions at $394 \mathrm{~nm}\left({ }^{7} \mathrm{~F}_{0} \rightarrow{ }^{5} \mathrm{~L}_{6}\right)$ and $464 \mathrm{~nm}\left({ }^{7} \mathrm{~F}_{0} \rightarrow{ }^{5} \mathrm{D}_{2}\right)$. The sodium cinnamate salt has two broad and intense absorption bands $\left(\lambda_{\max }=\right.$ $224 \mathrm{~nm}$ and $285 \mathrm{~nm}$, respectively) attributed to a mixture of $\pi \rightarrow \pi^{*}$ and $\eta \rightarrow \pi^{*}$ transitions [23]. The electronic transitions assigned to the absorption band in the $245-320 \mathrm{~nm}$ region correspond to the carboxyl group and aromatic ring of the cinammate anion. Due to its high UV absorption capacity in the $205-320 \mathrm{~nm}$ region, the cinnamate anion has frequently been used as sunscreens [10]. The hybrid material exhibits a similar absorption profile to the sodium cinnamate salt. Therefore, the hybrid demonstrates potential for applicability as a sunscreen. In addition, a red shift (bathochromic effect) of the absorption band in the $245-320 \mathrm{~nm}$ region is observed, indicating guest-host interactions. 

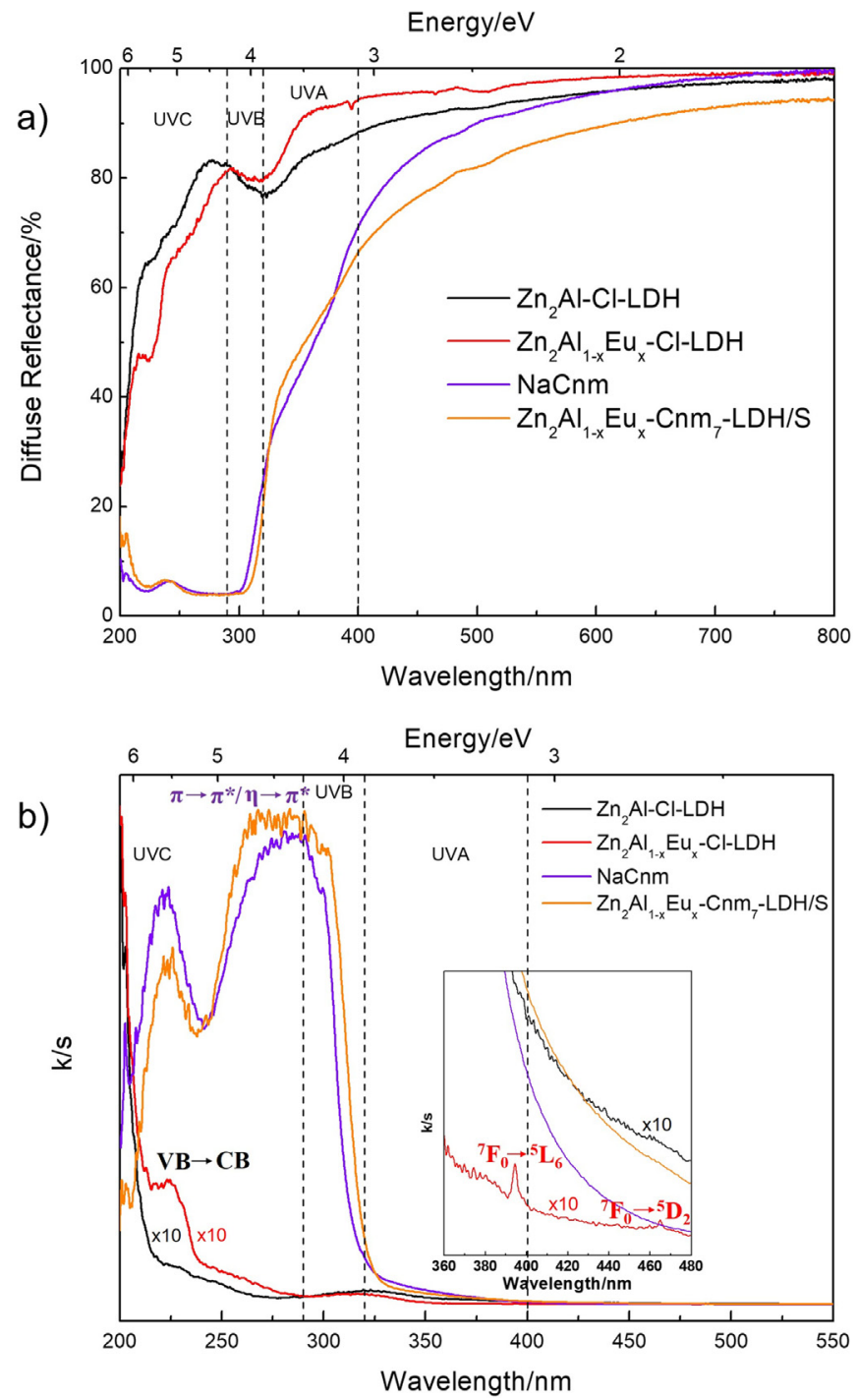

Fig. 4. a) Diffuse reflectance and b) absorption spectra of sodium cinnamate salt, $\mathrm{Zn}_{2} \mathrm{Al}-\mathrm{Cl}-\mathrm{LDH}, \mathrm{Zn}_{2} \mathrm{Al}_{1-\mathrm{x}} \mathrm{Eu}_{\mathrm{x}}-\mathrm{Cl}-\mathrm{LDH}$ and $\mathrm{Zn}_{2} \mathrm{Al}_{1-\mathrm{x}} \mathrm{Eu}_{\mathrm{x}}-\mathrm{Cnm}_{7}-\mathrm{LDH} / \mathrm{S}$.

The CIELab color diagram shows that the hybrid material has a yellowish-white pigment $\left(\mathrm{L}^{*}=93.6\right.$; $\mathrm{a}^{*}=-0.03$ and $\left.\mathrm{b}^{*}=6.03\right)$, the same as the sodium cinnamate salt $\left(\mathrm{L}^{*}=95.1 ; \mathrm{a}^{*}=-0.37\right.$ and $\mathrm{b}^{*}=6.20$ ); consequently, its use as a sunscreen does not compromise the aesthetics of the cosmetic product (see Fig. S2 in the Supplementary Material).

The excitation spectrum of the $\mathrm{Zn}_{2} \mathrm{Al}_{1-\mathrm{x}} \mathrm{Eu}_{\mathrm{x}}-\mathrm{Cnm}_{7}-\mathrm{LDH} / \mathrm{S}$ at room temperature (Fig. 5) shows a low intensity band $(250-305 \mathrm{~nm})$ probably an oxygen-to-metal charge transfer band (CT) and a broad and intense band at about $342 \mathrm{~nm}$ attributed to a mixture of $\pi \rightarrow \pi^{*}$ and $\eta \rightarrow$ $\pi^{*}$ transitions of the cinnamate anion. The excitation spectrum also exhibits narrow bands assigned to intraconfigurational $4 \mathrm{f}^{6}$ transitions of the $\mathrm{Eu}^{3+}$ ion $\left({ }^{7} \mathrm{~F}_{0} \rightarrow{ }^{5} \mathrm{~L}_{6}\right.$ at $394 \mathrm{~nm}$ and ${ }^{5} \mathrm{~F}_{\mathrm{J}} \rightarrow{ }^{5} \mathrm{D}_{2}$ at $\left.464 \mathrm{~nm}\right)$ [24]. The room-temperature emission spectra of the $\mathrm{Zn}_{2} \mathrm{Al}_{1-\mathrm{x}} \mathrm{Eu}_{\mathrm{x}}-\mathrm{Cnm}_{7}-\mathrm{LDH} / \mathrm{S}$ were recorded at excitation wavelengths $\left(\lambda_{\text {exc }}\right)$ of $290,335,394$ and $464 \mathrm{~nm}$ assigned to the charge transfer, cinnamate transition and intraconfigurational $4 \mathrm{f}^{6}$ transitions of the $\mathrm{Eu}^{3+}$ ion (shown in Fig. 5). Depending on the $\lambda_{\text {exc }}$ used, the emission spectrum shows red emission of the $\mathrm{Eu}^{3+}$ ion and cinnamate anion. Moreover, emission bands observed are broad and low-intensity $[25,26]$ due to the high amount of water and $\mathrm{OH}$ groups present in the $\mathrm{LDH}$, which provide nonradiative deactivation by multiphonon process.

Excitation and emission spectra were obtained at liquid nitrogen

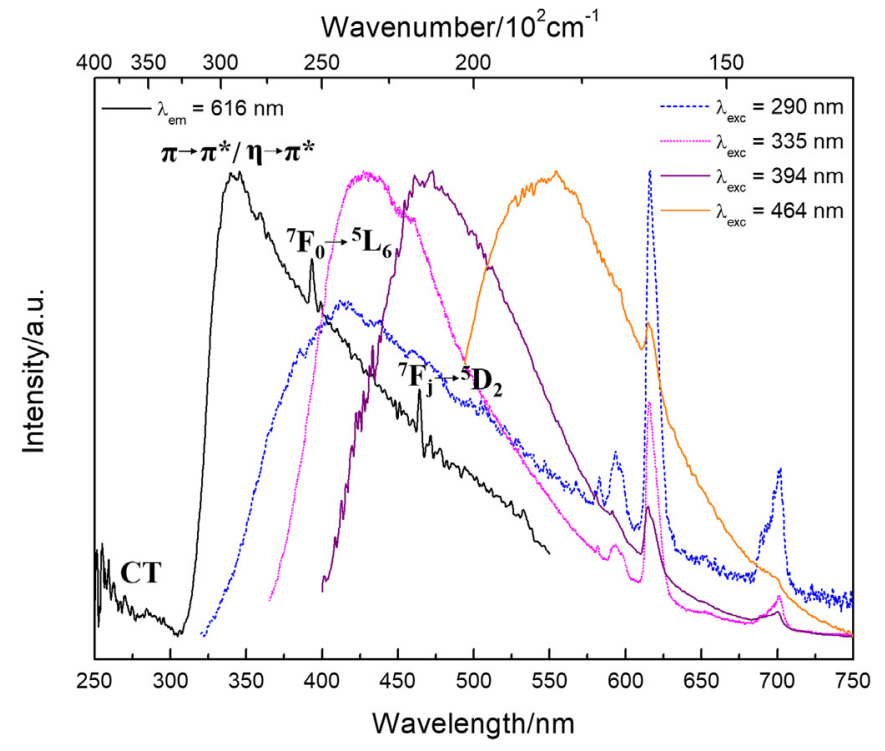

Fig. 5. Excitation and emission spectra of $\mathrm{Zn}_{2} \mathrm{Al}_{1-\mathrm{x}} \mathrm{Eu}_{\mathrm{x}}-\mathrm{Cnm} \mathrm{m}_{7} \mathrm{LDH} / \mathrm{S}$ at room temperature.

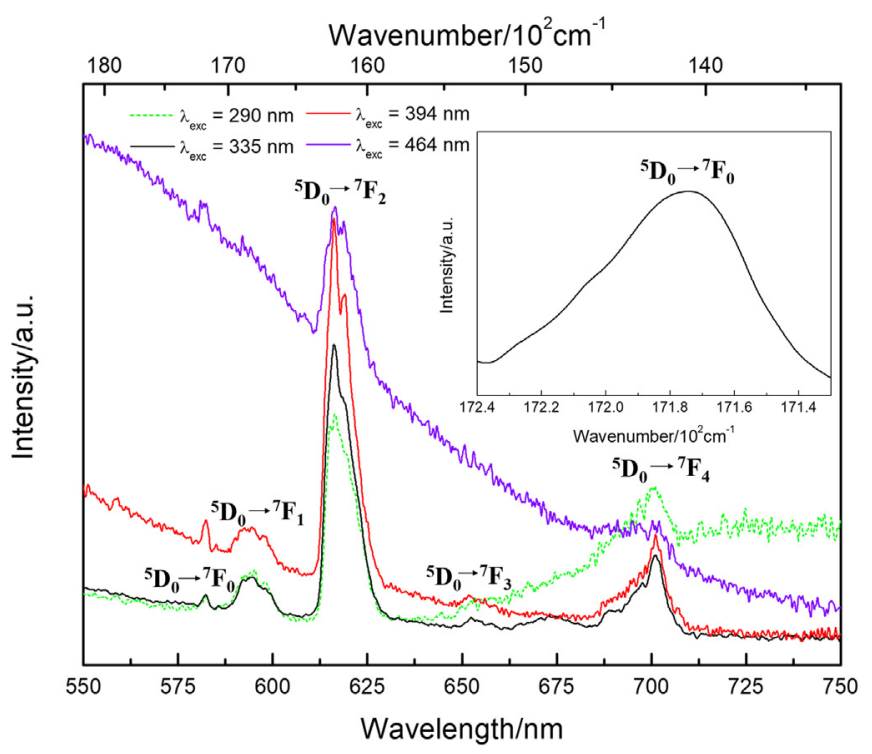

Fig. 6. Emission spectra of $\mathrm{Zn}_{2} \mathrm{Al}_{1-\mathrm{x}} \mathrm{Eu}_{\mathrm{x}}-\mathrm{Cnm}_{7}-\mathrm{LDH} / \mathrm{S}$ at $\sim 77 \mathrm{~K}$ under different excitation wavelengths.

temperature $(\sim 77 \mathrm{~K})$ in order to investigate the environment of the $\mathrm{Eu}^{3+}$ ions and understand the intramolecular energy transfer process in the layered material. In the emission spectra of the $\mathrm{Zn}_{2} \mathrm{Al}_{1-\mathrm{x}} \mathrm{Eu}_{\mathrm{x}}-\mathrm{Cnm}_{7^{-}}$ $\mathrm{LDH} / \mathrm{S}$ at $\sim 77 \mathrm{~K}$ (Fig. 6), the ${ }^{5} \mathrm{D}_{0} \rightarrow{ }^{7} \mathrm{~F}_{2}$ transition is more intense than the ${ }^{5} \mathrm{D}_{0} \rightarrow{ }^{7} \mathrm{~F}_{1}$ transition, which indicates that the $\mathrm{Eu}^{3+}$ ions occupy non-centrosymmetric sites [27]. In addition, the emission spectra exhibit a wide band (FWHM $=43 \mathrm{~cm}^{-1}$ ) in the $580-584 \mathrm{~nm}$ region attributed to the ${ }^{5} \mathrm{D}_{0} \rightarrow{ }^{7} \mathrm{~F}_{0}$ transition. This indicates that $\mathrm{Eu}^{3+}$ ions are in a close environment as observed in glasses due to inhomogeneous line broadening [28]. The number of crystal-field components for the ${ }^{5} \mathrm{D}_{0} \rightarrow$ ${ }^{7} \mathrm{~F}_{\mathrm{J}}$ transitions $(J=0-4)$ observed in the emission spectra shows that $\mathrm{Eu}^{3+}$ ions occupy low symmetry sites [14].

In the excitation spectra of $\mathrm{NaCnm}$ at liquid nitrogen temperature (Fig. 7), the vibronic transitions of the carboxylate group are observed. The emission spectrum of NaCnm at $\sim 77 \mathrm{~K}$ (Fig. 7) shows a broad emission band with maximum value at $489 \mathrm{~nm}\left(2.04 \times 10^{4} \mathrm{~cm}^{-1}\right)$ extending up to $\sim 667 \mathrm{~nm}\left(1.50 \times 10^{4} \mathrm{~cm}^{-1}\right)$ similar to the emission bands of aromatic carbonyl compounds $[29,30]$, which are assigned to 


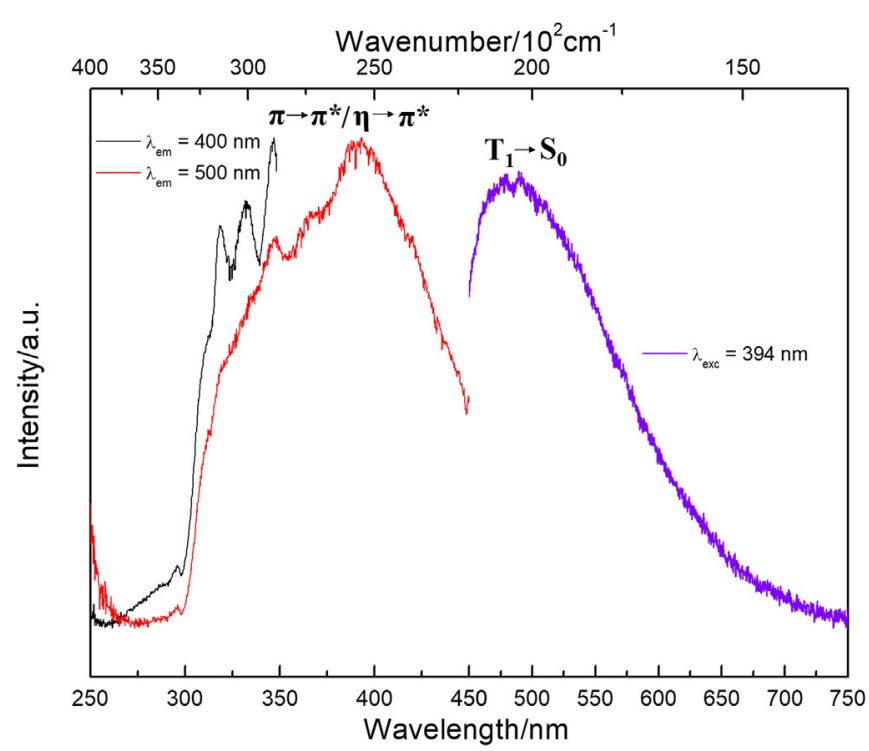

Fig. 7. Excitation and emission spectra of $\mathrm{NaCnm}$ at $\sim 77 \mathrm{~K}$.

triplet-singlet transition. This indicates that the cinnamate anion is not a suitable molecule for the energy transfer process (antenna effect) in the $\mathrm{Zn}_{2} \mathrm{Al}_{1-\mathrm{x}} \mathrm{Eu}_{\mathrm{x}}-\mathrm{Cnm}_{7}-\mathrm{LDH} / \mathrm{S}$ material. Therefore, the $\mathrm{Zn}_{2} \mathrm{Al}_{1-\mathrm{x}} \mathrm{Eu}_{\mathrm{x}}-$ $\mathrm{Cnm}_{7}-\mathrm{LDH} / \mathrm{S}$ material presents low-intensity emission in the 550-750 nm spectral region. However, UVB (290-320 nm) and UVA $(320-400 \mathrm{~nm})$ radiations absorbed by the $\mathrm{Eu}^{3+}$ doped layered material are converted into low-intensity red light emission of the cinnamate anion (wide emission band) and $\mathrm{Eu}^{3+}$ ion (narrow emission bands).

\section{Conclusions}

The Eu(III) doped $\mathrm{Zn}_{2} \mathrm{Al}-\mathrm{LDH}$ intercalated with cinammate anions with $\mathrm{C}_{9} \mathrm{H}_{7} \mathrm{O}_{2}{ }^{-} / \mathrm{M}^{3+}=5$ and 7 molar ratios were successfully synthesized by different anion-exchange methods. Structural analysis shows the formation of layered materials composed of both LDH intercalated with cinammate anions and LDH intercalated with chloride anions. In addition, this analysis pointed to a bilayer arrangement of cinammate anions in the interlayer region, where its associated carboxylate groups are close to the positive LDH layers. The UV-VIS absorption spectra indicate that hybrid materials exhibit high UV shielding ability, whereas luminescence spectra show red emission of the $\mathrm{Eu}^{3+}$ and the cinnamate ions of low intensity to be a phosphor but potentially capable of inducing collagen production. Therefore, optical properties of the $\mathrm{Eu}(\mathrm{III})$ doped $\mathrm{Zn}_{2} \mathrm{Al}$-LDH intercalated with cinammate anions allow their use as multifunctional sunscreens.

\section{Acknowledgments}

This work was developed with institutional infrastructure financed by FAPESP, CNPq and CAPES (Brazilian Agencies), as well as from CNPq grant number 312482/2013-2. G.P.S thanks CAPES for the granted scholarship.

\section{Appendix A. Supporting information}

Supplementary data associated with this article can be found in the online version at https://doi.org/10.1016/j.jlumin.2018.06.039.

\section{References}

[1] J. Kockler, M. Oelgemöller, S. Robertson, B.D. Glass, J. Photochem. Photobiol. C 13 (2012) 91-110.

[2] R. Losantos, D. Sampedro, M.S. Churio, Pure Appl. Chem. 87 (2015) 979-996.

[3] O.I. Parisini, D. Aiello, M.F. Casula, F. Puoci, R. Malivindi, L. Scrivano, F. Testa, RSC Adv. 6 (2016) 83767-83775.

[4] M.E.A. Chaves, A.R. Araujo, A.C.C. Piancastelli, M. Pinotti, An. Bras. Dermatol. 89 (2014) 616-623.

[5] A. Mamalis, E. Koo, M. Garcha, W.J. Murphy, R.R. Isseroff, J. Jagdeo, J. Biophotonics 9 (2016) 1167-1179.

[6] V.R.R. Cunha, A.M.C. Ferreira, V.R.L. Constantino, J. Tronto, J.B. Valim, Quim. Nova 33 (2010) 159-171.

[7] H. Yin, Z. Tang, Chem. Soc. Rev. 45 (2016) 4873-4891.

[8] Q. He, S. Yin, T. Sato, J. Phys. Chem. Solids 65 (2004) 395-402.

[9] L. Perioli, M. Nocchetti, V. Ambrogi, L. Latterini, C. Rossi, U. Costantino, Microporous Mesoporous Mater. 107 (2008) 180-189.

[10] Y. Li, L.P. Tang, X. Ma, X.R. Wang, W. Zhou, D.S. Bai, J. Phys. Chem. Solids 107 (2017) 62-67.

[11] T. Posati, F. Costantino, L. Latterini, M. Nocchetti, M. Paolantoni, L. Tarpani, Inorg. Chem. 51 (2012) 13229-13236.

[12] Z. Zhang, G.M. Chen, J.G. Liu, RSC Adv. 4 (2014) 7991-7997.

[13] Y.F. Chen, Y. Bao, Z.P. Yu, G.C. Yang, L. Zhang, J. Lumin. 181 (2017) 71-77.

[14] K. Binnemans, Coord. Chem. Rev. 295 (2015) 1-45.

[15] K. Binnemans, Chem. Rev. 109 (2009) 4283-4374.

[16] F.L. Theiss, G.A. Ayoko, R.L. Frost, Appl. Surf. Sci. 383 (2016) 200-213.

[17] A.A.A. Ahmed, Z.A. Talib, M.Z. bin Hussein, A. Zakaria, J. Solid State Chem. 191 (2012) 271-278.

[18] V.R.R. Cunha, P.A.D. Petersen, M.B. Goncalves, H.M. Petrilli, C. Taviot-Gueho, F. Leroux, M.L.A. Temperini, V.R.L. Constantino, Chem. Mater. 24 (2012) 1415-1425.

[19] S. Miyata, Clays Clay Miner. 31 (1983) 305-311.

[20] S.J. Palmer, R.L. Frost, T. Nguyen, Coord. Chem. Rev. 253 (2009) 250-267.

[21] K. Nakamoto, Infrared and Raman Spectra of Inorganic Compounds, fifth ed., John Wiley \& Sons, New York, 1997.

[22] S.K. Loyalka, C.A. Riggs, Appl. Spectrosc. 49 (1995) 1107-1110.

[23] D.L. Pavia, G.M. Lampman, G.S. Kriz, J.A. Vyvyan, fourth ed., Cengage Learning, Belmont, 2009.

[24] G.F. de Sá, O.L. Malta, C.M. Donegá, A.M. Simas, R.L. Longo, P.A. Santa-Cruz, E.F. da Silva Jr, Coord. Chem. Rev. 196 (2000) 165-195.

[25] Y.F. Chen, S.H. Zhou, F. Li, Y.W. Chen, J. Mater. Sci. 45 (2010) 6417-6423.

[26] Y.F. Chen, F. Li, S.H. Zhou, J.C. Wei, Y.F. Dai, Y.W. Chen, J. Solid State Chem. 183 (2010) 2222-2226.

[27] G. Blasse, B.C. Grabmaier, Luminescent Materials, Springer, Berlin, 1994.

[28] V. Lavin, U.R. Rodriguez-Mendoza, I.R. Martin, V.D. Rodriguez, J. Non-Cryst. Solids 319 (2003) 200-216.

[29] E.C. Lim, Y.H. Li, R. Li, J. Chem. Phys. 53 (1970) 2243-2248.

[30] T. Itoh, J. Lumin. 109 (2004) 221-225. 